Martina Ireinová, Petra Přadková, eds.:

Obščeslavjanskij lingvističeskij atlas, serija fonetiko-grammatičeskaja, vypusk 9. Refleksy *tort, *tolt, "tert, "telt, *ort, *olt.

Praha: Academia, 2019.

ISBN 978-80-200-3105-1

S vročením 2019 byl vydán 9. svazek foneticko-gramatické série Slovanského jazykového atlasu (OLA) s názvem Reflexy *tort, *tolt, *tert, ${ }^{*}$ telt, ${ }^{*}$ ort, ${ }^{*}$ olt. Slovanský jazykový atlas, ${ }^{1}$ který sestává z map věnovaných dialektům slovanských jazyků, vychází ve dvou sériích: foneticko-gramatické (dosud bylo publikováno 9 svazků) a lexikálně-slovotvorné (prozatím bylo vydáno 10 svazků). Myšlenka na vznik atlasu byla zformulována na IV. mezinárodním sjezdu slavistů v Moskvě roku 1958. Terénní výzkum zaměřený na sběr nářečního materiálu byl uskutečněn podle dotazníku o 3454 otázkách v 60. a 70. letech minulého století v 853 lokalitách, z nichž se na území Čech, Moravy a Slezska nachází celkem 33.

Vydání nejnovějšího svazku připravily členky dialektologického oddělení ÚJČ AV ČR, v. v. i., Martina Ireinová a Petra Přadková, které navázaly na práci Karla Fice († 2005), jenž př́pravu tohoto svazku započal. Svazek připravený českou redakční radou je zaměřen na praslovanské skupiny *or, *ol, *er, *el v interkonsonantické pozici (*tort - 25 map, *tolt - 18 map, *tert - 16 map, *telt - 9 map) i v náslovné pozici (*ort - 9 map, *olt - 2 mapy), jejichž změna byla ve většině slovanských dialektů spjata s metatezí likvid. Společně s N. Antropovem a P. Gricenkem vypracovaly autorky úvodní studii, která pojednává o stavu zkoumaných hláskových skupin v nářečích slovanských jazyků. Studie uvádí zajímavá zjištění, která výzkum těchto hláskových skupin přinesl. Jedná se např. o popis vlivu sousedících slovanských dialektů v oblastech mezijazykového kontaktu.

Celkem svazek obsahuje 79 map a doplňujících materiálů, na jejichž vzniku se podíleli jazykovědci z akademických a univerzitních pracovišt' 13 zemí. Součástí každé mapy je legenda a stručný komentář popisující nepravidelné hláskové jevy a vedle mapy je umístěn soupis všech lokalit výzkumu se zachycenými výrazy.

Pro zobrazení nářečního materiálu na mapách byly využity především modifikované plošné symboly. Tyto symboly doplňují lineární značky (týkající se např. intonace). Systém symbolů byl oproti předchozím svazkům foneticko-gramatické série pozměněn, jelikož stávající systém nebyl dostatečný pro zaznamenání složité situace výsledků metatezí likvid. Vznikla tak nová legenda (ovály pro plnohlasí, půlovály pro neplnohlasí a jiné symboly pro diftongy).

Jednotlivé svazky OLA jsou postupně převáděny do elektronické podoby a zveřejňovány na webové stránce projektu. ${ }^{2}$ Tištěná forma svazku Reflexy *tort, *tolt, *tert, *telt, *ort, *olt bude tedy v budoucnu dostupná i v digitalizované verzi.

1 Informace o historii projektu byly čerpány z: KLOFERová, Stanislava. 2015. Nářeční atlasy slovanských jazyků. Historie a současnost. Gwary Dziś 7, s. 43-55.

2 Obščeslavjanskij lingvističeskij atlas [online]. [cit. 22.6.2020]. Dostupné z: http://slavatlas.org/index.html 
Poděkování: Tento př́spěvek vznikl na základě řešení projektu MUNI/A/o913/2019 (ID=54551) Čeština $v$ jednotě synchronie a diachronie - 2020 .

\section{Tereza Kopecká}

Department of Czech Language

Faculty of Arts, Masaryk University

Arna Nováka 1, 602 oo Brno

Czech Republic

kopecka@mail.muni.cz 